\section{Development, inequality, and war in Africa}

\section{E. Wayne Nafziger}

The four horsemen of the apocalypse war, disease, hunger, and displacement - characterize many African lives. Indeed, about 20 percent of Africans live in countries seriously disrupted by war or state violence.
7 he four horsemen of the apocalypse - war, disease, hunger, and displacement characterize many African lives. Indeed, about twenty percent of Africans live in countries seriously disrupted by war or state violence. The cost of conflict includes refugee flows, rising military expenditure, damage to transport and communication facilities, reduction in trade and investment, and diversion of resources from development. The World Bank estimates that a civil war in an African country lowers its per capita output by 2.2 percentage points annually. ${ }^{1}$ The 800,000 estimated deaths (11 percent of the population) from genocide in Rwanda represented perhaps the highest non-natural casualty rate in history. ${ }^{2}$ Other African emergencies in recent years include Algeria, Angola, Burundi, Chad, Congo-Brazzaville, Congo-Kinshasa, Guinea-Bissau, Eritrea, Ethiopia, Liberia, Mozambique, Sierra Leone, Somalia, South Africa, Sudan, and Uganda.

This article relates how the political economy of African states affects humanitarian emergencies, defined as a human-made crisis in which large numbers of people die and suffer from war, state violence, and refugee displacement. Humanitarian emergencies are directly correlated with declining incomes, high income inequality, competition for extraction of mineral wealth, military centrality as defined by military expenditure as a percentage of GNP, and conflict tradition. In contrast to a widely-held belief, ethnic differences are a symptom, not a cause, of conflict.

Income stagnation and decline

Contemporary emergencies are found only in developing countries, suggesting a threshold above which war and massive state violence almost never occur.
Contemporary emergencies are found only in developing countries, suggesting a threshold above which war and massive state violence almost never occur. A disproportional number of these states are also weak or failing, ${ }^{3}$ a trait that interacts as both cause and effect of their relative poverty. Moreover, emergencies are more likely to occur in countries experiencing economic stagnation, which affects relative deprivation, the actors' perception of social injustice from a discrepancy between goods and conditions they expect and those they can get and keep. This deprivation spurs social discontent, which provides motivation for collective violence. Tangible and salient factors such as a marked deterioration of living conditions, especially during a period of high expectations, are more likely to produce socio-political discontent that may be mobilized into political violence. War and violence, moreover, have major catalytic roles, adding to social disruption and political instability, undermining economic activity, spreading hunger and disease, and increasing refugee flows.

Only a portion of violence results from insurgent action. In fact, the policies of governing elites are at the root of most humanitarian emergencies. Slow or negative growth puts ruling coalitions on the

horns of a dilemma. Ruling coalitions can expand profit-seeking opportunities for existing political elites, contributing to further economic stagnation that can threaten the legitimacy of the regime and increase the probability of regime turnover. To forestall threats to the regime, political elites may use repression to suppress discontent or capture a greater share of the majority's shrinking surplus. These repressive policies may entail acts of direct violence against or withholding food and other supplies from politically disobedient groups, as in Sudan in the 1980's. ${ }^{4}$ Moreover, repression and economic discrimination may generate relative deprivation and trigger affected groups to mobilize, leading to further violence and worsening the humanitarian crisis.

Since economic deceleration or collapse can disrupt ruling coalitions and exacerbate mass discontent, we should not be surprised that since 1980, Africa has been especially vulnerable to humanitarian emergencies. This increase in civil conflict and humanitarian emergencies in Africa in the last two decades of the twentieth century is linked to its negative per capita growth in the 1970's and 1980's and virtual stagnation in the 1990's. Indeed in Africa, which had the highest death rate from wars, output per capita was lower in the late 1990's than it was at the end of the 1960 's. ${ }^{5}$

In Africa, falling average incomes and growing political consciousness added pressures on national leaders, whose response was usually not only anti-egalitarian but also anti-growth: depressing returns to small farmers, appropriating peasant surpluses for state-run industry, building state enterprises beyond management capacity, and using these inefficient firms to give benefits to clients. Regime survival in a politically fragile system required expanding patronage to marshal elite support, at the expense of economic growth. ${ }^{6}$ Spurring peasant production through market 
prices and exchange rates would have interfered with state leaders' ability to build political support, especially in cities.

Africa's economic crisis in the 1980's and early 1990's originated from its inability to adjust to the 1973-74 oil shock, exacerbated by a credit cycle in which states borrowed heavily at negative real interest rates in the mid to late 1970's, but faced high positive rates during debt servicing or loan renewal in the 1980's. African leaders' economic policies during the 1970's and early 1980's emphasized detailed state planning, expansion of government-owned enterprises, heavy-industry development, and government intervention in exchange rates and agricultural pricing. These policies contributed to economic decline and growing poverty (especially in rural areas) and inequality. The political elites used the state to pursue economic policies that supported their interests at the expense of Africa's poor and working classes.

\footnotetext{
Predatory rule involves a personalistic regime ruling through coercion, material inducement, and personality politics, tending to decay the institutional foundations of the economy and state.
}

This stagnation and decline contributed to political decay in the 1980's and early 1990's in such countries as Nigeria, Sierra Leone, Zaire, and Liberia. Ethnic and regional competition for the bounties of the state gave way to a predatory state. Predatory rule involves a personalistic regime ruling through coercion, material inducement, and personality politics, tending to degrade the institutional foundations of the economy and state. Elites do not benefit from avoiding political decay through nurturing free entry and the rule of law and reducing corruption and exploitation. Instead political leaders may gain more from extensive unproductive, profit-seeking activities in a political system they control than from long-term efforts to build a well-functioning state in which economic progress and democratic institutions flourish. These activities tend to be pervasive in countries that have abundant mineral exports (for example, diamonds and petroleum), such as Sierra Leone, Angola, Congo, and Liberia, while predatory economic behavior is less viable in mineral-export-poor economies such as Togo, Ghana, and Tanzania.

The majority of countries with humanitarian emergencies have experienced several years (or even decades) of negative or stagnant growth, where growth refers to real growth in output per capita. Virtually all emergencies in Africa in the 1990's that are listed above, except for Chad, were preceded by slow or negative economic growth. Contemporary humanitarian disaster is rarely episodic. It is usually the culmination of longer-term politico-economic decay over a period of a decade or more. Negative per capita growth interacts with political predation in a downward spiral, as seen in African countries such as Angola, Ethiopia, Sudan, Somalia,

\section{Liberia, Sierra Leone, and Zaire (Congo).}

Economic stagnation, frequently accompanied by chronic trade deficits and growing external debt, intensifies the need for economic adjustment and stabilization. A persistent external disequilibrium has costs whether countries adjust or not. But non-adjustment has the greater cost; the longer the disequilibrium, the greater is the social damage and the more painful the adjustment. ${ }^{7}$

More than a decade of slow growth, rising borrowing costs, reduced concessional aid, a mounting debt crisis, and the increased economic liberalism of donors and international financial institutions, compelled African elites to change their strategies during the 1980's and 1990's. Widespread economic liberalization and adjustment provided opportunities for challenging existing elites, threatening their positions, and contributing to increased opportunistic profit-seeking and overt repression. Cuts in spending reduced the funds to distribute to clients and required greater military and police support to remain in power.

\section{Income inequality}

Large income inequality increases the vulnerability of populations to humanitarian emergencies. Income inequality, by fueling social discontent, increases socio-political instability as measured by deaths in domestic disturbances and assassinations (per million population) and coups (both successful and unsuccessful). Moreover, the policies of predatory and authoritarian rulers increase income inequality.

Severe social tensions leading to humanitarian emergencies may even arise under conditions of positive (even rapid) growth and expanding resource availability. High inequality can contribute to the immiseration or absolute deprivation of portions of the population, even with growth. Absolute deprivation during substantial growth was experienced for instance by Igbo political elites, dominant in Nigeria's Eastern Region, in 1964-65. The East lost oil-tax revenues when the federal government ceased distributing mineral export revenues to regional governments.

A high degree of income inequality increases the perception of relative deprivation by substantial sections of the population even when these do not experience absolute deprivation. The risk of political disintegration increases with a surge of income disparities by class, region, and

community, especially when these disparities lack legitimacy among the population. Class and communal (regional, ethnic, and religious) economic differences often overlap, exacerbating perceived grievances and potential strife.
The risk of political disintegration increases with a surge of income disparities by class, region, and community, especially when these disparities lack legitimacy among the population. 
The trends and policies leading to this type of large income inequality result from historical legacies of discrimination (e.g., colonialism, apartheid, failed past policies), from government policies in distributing land and other assets, taxation, and the benefits of public expenditure, from regional and ethnic economic competition, and from predatory rule. Growing regional inequality and limited regional economic integration, associated with economic enclaves, can intensify ethnic and regional competition and conflict.

Regional factors contributing to conflict include educational and employment differentials, revenue allocation, and language discrimination, which disadvantages minority language communities. Examples include the struggle for petroleum tax revenues and employment in the civil service and modern sector in Nigeria in the early to mid-1960's, and the conflict between Hutu and Tutsi for control of the state and access to employment in Burundi and Rwanda.

While high inequality is associated with emergencies, insurgency is more likely if the less advantaged can identify the perpetuators of their poverty and suffering. The examples of Nigeria and South Africa ${ }^{8}$ illustrate the varied patterns of how discriminatory government policies cause economic inequality, fuel social discontent, and lead to political conflict and humanitarian emergencies. These dynamics may even occur when either the nation's real per capita GDP is growing, as in Nigeria in the 1960's, or when the disadvantaged group's economic position is improving, as for non-white South Africans from the 1960's through the early 1980's.

High income inequality can be a source of humanitarian emergencies in both rapidly and slowly-growing countries. However, once a population is dissatisfied with income discrepancies and social discrimination, as the majority nonwhites were in white-ruled South Africa, the rising expectations associated with incremental reductions in poverty and inequality may actually spur revolt, conflict, and state-hostile action that increases the probability of a humanitarian emergency. ${ }^{9}$

\section{Competition for minerals}

In the struggle for allies during the Cold War, the United States and the Soviet Union provided military and economic aid for African developing countries. Sovereignty provided the opportunity to extract resources from the major powers in exchange for diplomatic support. Yet aid could provide the basis for supporting a patronage system for either the state or for insurgents in opposition. When the Cold War ended in the early 1990's, nation-states and rebels in the developing world required different strategies and new sources of funds. Many African countries needed control of resources to provide military and police power but only minimal services to control territory. Indeed with the IMF/World Bank emphasis on the market and private enterprise, rulers often undermined their own bureaucracies to build personal power at the expense of health, education, and agricultural development. ${ }^{10}$
The struggle for control over minerals is an important source of conflict. In Angola, Sierra Leone, Liberia, and Congo-Kinshasa, rulers and warlords used exclusive contracts with foreign firms for diamonds and other minerals to "regularize" sources of revenue in lieu of a government agency to collect taxes. ${ }^{11}$ After the decrease in aid after the Cold War, Sierra Leone was more susceptible to pressures for liberalization and adjustment from the IMF and World Bank. In 1991, the IMF, the Bank, and bilateral creditors offered loans and debt rescheduling worth $\$ 625$ million, about 80 percent of GNP, if Sierra Leone reduced government expenditure and employment. In response, Freetown heeded the World Bank's advice $^{12}$ to use private operators to run state services for a profit. But privatization did not eliminate the pressures of clients demanding payoffs; it merely shifted the arena of clientage to the private sector. Sierra Leone's ruling elites, needing new ways of exercising power, used foreign firms to consolidate power and stave off threats from political rivals. In the 1990's, Sierra Leonean heads of state relied on exclusive contracts with foreign firms for diamond mining to regularize revenue, foreign mercenaries and advisors to replace the national army in providing security, and foreign contractors (sometimes the same mining or security firms) to provide other state services. In the process, rulers have found it advantageous to destroy state agencies, to "cleanse" them of politically threatening patrimonial hangers-on and to use violence to extract resources from people under their control. ${ }^{13}$

In Liberia, Charles Taylor used external commercial networks (foreign firms), some a legacy of the Sam Doe regime of the late 1980 's, to amass power over Liberia, and at times, the eastern periphery of Sierra Leone. Taylor's territory had its own currency and b a n k i n g s y s t e m , telecommunications network, airfields, export trade (in diamonds, timber, gold, and farm products) to support arms imports, and (until 1993) a deepwater port. For Taylor, a warlord during most of the 1990' s before being elected Liberia's president in 1997, controlling territory by building a patronage network was easier than building a state and its bureaucracy. ${ }^{14}$ Indeed, Taylor had access to annual revenues exceeding \$100 million, with an upper limit around \$200 million, from 1990 to 1996. $^{15}$

Even Zaire’s President Mobutu Sese Seko (1965-1997), like other hard-pressed rulers in weak African states, mimicked the "warlord" approach of his non-state rivals. But with the shrinking patronage base from foreign aid and investment, to prevent a coup by newly marginalized groups in the army or bureaucracy, Mobutu, similar to rulers in other retrenching African states, needed to reconfigure his political 
authority. In this situation, foreign firms and contractors served as a new source of patronage networks. However, indigenous commercial interests that profit from the new rules are not independent capitalists with interests distinct from the state's. Indeed those who do not take part in accumulation on the ruler's terms are punished. Mobutu weathered the collapse of the state bureaucracy, but fell because his strategy of milking state assets had reached a limit, seriously weakening the patronage system. In 1997, his forces fell to the Alliance des Forces Democratique pour la Liberation (AFDI) of Laurent Kabila, the eventual president of the Democratic Republic of Congo until his assassination in $2001 .^{16}$

\begin{abstract}
Rulers, warlords, and traders are more likely to profit from war and violence than from peace. Indeed, war, political violence, and state failure do not result from the incapacity of public institutions but from the fact that rulers, warlords, and their clients benefit from the harm thereby befalling a substantial share of the population.
\end{abstract}

State failure, as in Sierra Leone, Liberia, and Zaire, increases vulnerability to war and humanitarian emergencies. Yet, in a weak or failed state, some rulers, warlords, and traders are more likely to profit from war and violence than in peacetime. Indeed, war, political violence, and state failure do not result from the incapacity of public institutions but from the fact that rulers, warlords, and their clients benefit from the harm thereby befalling a substantial share of the population. Relative deprivation also helps explain the increased violence by belligerents and their clients. An abrupt rush of mineral wealth not only increases the expectations of prosperity by the allies of those controlling the resource, but also lures potential rebels toward combat as a means to gain control of it for themselves. Indeed, the intensity of deprivation increases with the discrepancy between potential and actual conditions, and with the length of time the deprivation persists. In Angola, Congo-Kinshasa, and Sierra Leone, the length and intensity of perceived deprivation were considerable.

\section{Other factors}

The military burden - the ratio of military expenditure to GDP - also contributes to humanitarian emergencies. On the one hand, military resources are used to support authoritarian political structures which generate desperate action and military response by the opposition. Under political deprivation and in the absence of political mechanisms to settle grievances, full-scale rebellion becomes more likely. On the other hand, a strong military may overthrow either a democratic or an authoritarian regime which may lead to political instability and humanitarian crises. Powerful armed forces constitute a constant threat to civilian regimes in less-developed countries. Particularly during economic austerity, regimes are afraid to cut back on military expenditure. Furthermore, they may strengthen the military to stave off threats from the opposition. This, in turn, entails heavy socio-economic costs for the population, inducing further discontent and increasing the risk of rebellion. In very poor countries, an increasing budget allocation for the military may produce downright starvation and destitution. Citizens adapt to a certain, acceptable level of violence through the cultural experience of violence. A tradition of intensive political violence makes societies more susceptible to war and humanitarian emergencies. Countries with a history of mass political mobilization for conflict, such as Sudan, Rwanda, and Burundi, are likely to be more susceptible to humanitarian emergencies than other, historically more peaceful countries. Conflict tradition is an indicator of the legitimacy of political violence.

Ethnic identity is not a primordial “given.” Ethnicity, when implicated in humanitarian emergencies, is created, manifested, combined, and reconstituted in struggles to share benefits from modernization and self-government but is not a source of these struggles. ${ }^{17}$ Elites use identification with ethnic and regional communities, and even accentuate that identification, to transfer potential hostility from inequalities and power disparities within their communities to the elites and subjects of other communities. Ethnic antagonism emerges during conflict rather than being the cause of conflict. ${ }^{18}$

In the 1980's in South Africa, ethnic consciousness and cleavages were deliberately aroused as part of the government's attempt to divide and rule, implemented through the security apparatus. Chief Mangosuthu Buthelezi of the Zulubased Inkatha Freedom Party used cultural symbolism to strengthen his and his party's political power. During the most violent phase of the conflict in 1991-93, ethnic identities became further strengthened and reified, and their relevance as sources of political mobilization increased. ${ }^{19}$ In Somalia, President Siad Barre succeeded in holding power for 13 years after his failed military campaign in the Ogaden in 1977-78 by manipulating clan identities and thus dividing the opposition into different movements. However, this strategy led to his ousting in 1991. By having fueled clan antagonisms, Barre made the instrumental use of clan affinities much easier for his opponents who could build on his work. ${ }^{20}$ 


\section{Conclusion}

Five factors in particular contribute to humanitarian crises in Africa. They are: stagnating and declining incomes, rising income inequality, avaricious competition to extract Africa's mineral wealth, military centrality, and a tradition of violent conflict. One factor turns out to be a symptom, not a cause of violence: ethnic differences.

Since low average income, slow economic growth, and high income inequality are important contributors to emergencies, African states, with the support of the international community, must strengthen and restructure the political economy of poor, economically stagnant, and inegalitarian countries. The major changes Africa needs to make are economic and political institutional changes - the development of a legal system, enhanced financial institutions, increased taxing capacity, greater investment in basic education and other forms of social capital, well-functioning resource and exchange markets, programs to target weaker segments of the population, and democratic institutions that accommodate and co-opt the country's various ethnic and regional communities. Institutional and infrastructure development increases the productivity of private investment and public spending and enhances the effectiveness of governance.

Industrialized countries and international agencies bear substantial responsibility for modifying the international economic order to enhance economic growth and adjustment. Africa can demand greater consideration of its economic interests within present international economic and political institutions. The interests of Africa can generally be served by its enhanced flexibility and self-determination in designing paths toward adjustment and liberalization; a shift in the goals and openness of the IMF and World Bank; the restructuring of the international economic system for trade and capital flows; the opening of rich countries' markets; more technology transfer by foreign companies, bilateral donors, and international agencies; a greater coherence of aid programs; and increased international funding to reduce food crises, directly help the poor, ameliorate external shocks, and write down debt burdens.

A number of African countries vulnerable to humanitarian emergencies are not amenable to political economy solutions. Policies of governing elites are indeed at the root of most emergencies, and usually some powerful factions in society benefit from them. Yet a large number of African countries vulnerable to emergencies have the will to change. Thus, there is substantial scope for international, national, and nongovernmental economic and political actors to coordinate their long-term policies to reduce Africa’s vulnerability to humanitarian emergencies.

\section{Notes}

E. Wayne Nafziger is professor of economics at Kansas State University. This article is based on joint work with Juha Auvinen (University of Helsinki, Finland), a research project begun in 1996 by the United Nations University/World Institute for Development Economics Research (WIDER), in Helsinki, and conducted in collaboration with Queen Elizabeth House, Oxford, United Kingdom. It generalizes from eight African case studies of war-affected less-developed countries, 1980-2000, published as E. Wayne Nafziger, Frances Stewart, and Raimo Väyrynen (eds.) War, Hunger, and Displacement: The Origins of Humanitarian Emergencies, 2 vols, Oxford, Oxford University Press, 2000. The analysis draws on data on the relationship between humanitarian emergencies and their hypothesized sources, based on the annual observations from African and other developing countries during 1980-1995. A longer and fully documented version of this article is available directly from the author.

1. World Bank, 2000, pp. 57-59.

2. Prunier, 1995, pp. 264-265.

3. Holsti, 2000, pp. 243-250.

4. Keen, 2000, pp. 292-294.

5. World Bank, 2000, p. 1.

6. Nafziger, 1988.

7. Nafziger and Auvinen, 2000, p. 278.

8. Nafziger and Auvinen, 2000, pp. 105-108.

9. Davies, 1962, pp. 5-19.

10. Reno, 2000, pp. 231-232; Väyrynen 2000b, pp. 437-479.

11. Reno, 1996, 1998, 2000.

12. World Bank, 1994, pp. 22-51.

13. Reno, 1996, pp. 7-8, 12.

14. Reno, 1995, pp. 111. 
(C) www.epsjournal.org.uk - Vol. 1, No. 1 (2006)

15. Reno 2000a, pp. 243, 252.

16. Reno, 1998, pp. 147-181.

17. Nafziger et al., 2000.

18. Auvinen and Kivimaki 1998, p. 42; Taylor and Shaw, 1992.

19. Auvinen and Kivimaki, 2000, pp. 187-230.

20. Nafziger and Väyrynen, 2002.

\section{List of references}

Ake, C. 1996. Democracy and Development in Africa. Washington, DC: Brookings Institution.

Alexander, J., J.A. McGregor, and T. Ranger. 2000. "Ethnicity and the Politics of Conflict: The Case of Matabeleland.” In Nafziger, Stewart, and Väyrynen, eds., vol. 1, pp. 305-331.

Auvinen, J. and T. Kivimäki. 1998. "Early Warning and Conflict Management in South African Democratic Transition.” Acta Politica no. 7, Department of Political Science, University of Helsinki.

Auvinen, J. and T. Kivimäki. 2000. “Somalia: The Struggle for Resources.” In Nafziger, Stewart, and Väyrynen, eds., vol. 1, pp. 187-230.

Collier, P. 2000b. "Economic Causes of Civil Conflict and Their Implications for Policy.” Washington, DC: World Bank.

Davies, J.C. 1962. “Toward a Theory of Revolution.” American Sociological Review 27(1):5-19.

Holsti, K.J. 2000. “Political Causes.” In Nafziger, Stewart, and Väyrynen, eds., vol. 1, pp. 239-281.

Keen, D. 2000. “War, Crime, and Access to Resources.” In Nafziger, Stewart, and Väyrynen, eds., vol. 1, pp. 283-304.

Nafziger, E.W. 1988. Inequality in Africa: Political Elites, Proletariat, Peasants, and the Poor. Cambridge: Cambridge University Press.

Nafziger, E.W. and J. Auvinen. 2000. "Economic Causes: The Political Economy of War, Hunger, and Flight.” In Nafziger, Stewart, and Väyrynen, eds., vol. 1, pp. 91-145.

Nafziger, E.W., F. Stewart, and R. Väyrynen, eds. 2000. War, Hunger, and Displacement: The Origins of Humanitarian Emergencies. 2 vols. Queen Elizabeth House Series in Development Economics and UNU/World Institute for Development Economics Research Studies in Development Economics. Oxford:
Oxford University Press.

Nafziger, E.W. and R. Väyrynen, eds. 2002. The Prevention of Humanitarian Emergencies. Houndmills, UK: Palgrave.

Prunier, G. 1995. The Rwanda Crisis, 1959-1994: History of a Genocide. London: Hurst \& Co.

Reno, W. 1996. "Ironies of Post-Cold War Structural Adjustment in Sierra Leone.” Review of African Political Economy No. 67 (March):7-18.

Reno, W. 1998. Warlord Politics and African States. Boulder, CO: L. Rienner.

Reno, W. 2000. "Liberia and Sierra Leone: The Competition for Patronage in Resource-Rich Economies.” In Nafziger, Stewart, and Väyrynen, eds., vol. 2, pp. 231-259.

Väyrynen, R. 2000a. “Complex Humanitarian Emergencies: Concepts and Issues.” In Nafziger, Stewart, and Väyrynen, eds., vol. 1, pp. 43-89.

Väyrynen, R. 2000b. "Weak States and Humanitarian Emergencies: Failure, Predation, and Rent-seeking.” In Nafziger, Stewart, and Väyrynen, eds., vol. 2, pp. 437-479.

World Bank. 1994. World Development Report. New York: Oxford University Press. World Bank. 2000. Can Africa Claim the 21st Century? Washington, DC: World Bank. 